\section{Autochthonous canine visceral leishmaniasis in a non-endemic area: Bom Sucesso, Minas Gerais State, Brazil}

\author{
Ocorrência de leishmaniose visceral canina \\ autóctone em uma área não-endêmica: \\ Bom Sucesso, Minas Gerais, Brasil
}

\author{
${ }^{1}$ Núcleo de Qualidade \\ do Leite, Saúde Animal e \\ Socioeconomia, Embrapa \\ Gado de Leite, Juiz de Fora, \\ Brasil. \\ 2 Faculdade de Medicina, \\ Universidade Federal de \\ Minas Gerais, Belo Horizonte, \\ Brasil. \\ 3 Pró-Reitoria de Pós- \\ Graduação e Pesquisa, \\ Universidade Federal de \\ Alfenas, Alfenas, Brasil. \\ 4 Centro de Pesquisa René \\ Rachou, Fundação Oswaldo \\ Cruz, Belo Horizonte, Brasil. \\ 5 Departamento de Medicina \\ Veterinária, Universidade \\ Federal de Lavras, Lavras, \\ Brasil. \\ 6 Instituto de Ciências Exatas \\ e Biológicas, Universidade \\ Federal de Ouro Preto. \\ Ouro Preto, Brasil. \\ Correspondence \\ M. R. Silva \\ Núcleo de Qualidade do \\ Leite, Saúde Animal e \\ Socioeconomia, Embrapa \\ Gado de Leite. \\ Rua Eugênio do Nascimento \\ 610, Juiz de Fora, $M G$ \\ 36038-330, Brasil. \\ mrsilva@cnpgl.embrapa.br
}

\begin{abstract}
The article begins by describing a dog with characteristic symptoms of visceral leishmaniasis. A serum sample from this animal was positive by indirect immunofluorescence (IIF) performed in anti-Leishmania total IgG in 1999. Tissues from the same dog were also positive by polymerase chain reaction (PCR) in 2004, identifying Leishmania DNA in the cerebellum, liver, kidney, and intestine. This is the first report of a dog with autochthonous visceral leishmaniasis in the county of Bom Sucesso, Minas Gerais State, Brazil. The finding of this IIF-positive dog led to a canine visceral leishmaniasis epidemiological investigation in the county. The investigation was conducted from March 1999 to December 2005. IIF was positive for Leishmania in 22 (3\%) of 734 examined dogs. Among the 22 IIF-positive dogs, six presented characteristic symptoms of canine visceral leishmaniasis. The results of this epidemiological investigation were sent to local and State public health authorities, requesting visceral leishmaniasis control and preventive measures to interrupt transmission of the disease and avoid the occurrence of human cases.
\end{abstract}

Visceral Leishmaniasis; Dogs; Zoonoses

\author{
Marcio Roberto Silva 1,2 \\ Marcos José Marques ${ }^{3}$ \\ Alvaro José Romanha 4 \\ Idael Christiano de Almeida Santa-Rosa 5 \\ Cláudia M. Carneiro 6 \\ Alexandre Barbosa Reis 6
}

\section{Introduction}

In the Americas, Leishmania (Leishmania) chagasi is the etiological agent of visceral leishmaniasis in humans and dogs. Dogs play an important role in maintaining the disease cycle, since they act as reservoirs for this protozoan 1,2. When symptomatic, the most frequent clinical changes are: lymphadenomegaly followed by dermatological changes (hair loss, ulcerative lesions, intense itching, opaque fur, and seborrheic dermatitis); decreased appetite; onychogryphosis; and emaciation 3

Visceral leishmaniasis, an important public health problem, is currently more common than 50 years ago, occurring in areas previously considered non-endemic in Latin America 4 . Visceral leishmaniasis initially maintained a rural profile with peridomiciliary transmission. The disease has gradually acquired periurban characteristics, and there are now several urbanized areas with the disease in Brazil 5,6. Environmental degradation with the extensive destruction of primary forests and concomitant establishment of dwellings in clearings has fostered greater proximity among humans, the vector Lutzomyia longipalpis, and the reservoirs (dogs and foxes) 7,8, with the establishment of new transmission cycles. Other factors have also contributed to visceral leishmaniasis urbanization in many Latin American cities, like rural exodus, the consequent formation and extension of poverty in 
urban area, and the adaptation of sandflies to human-modified environments 4,7,8,9,10.

Importantly, molecular and biological analyses of $L$. (L.) chagasi samples have shown a clear similarity among parasites isolated from humans and dogs, reinforcing the role of these animals in the urbanization of the disease 11. In this context, the prevalence of canine visceral leishmaniasis in endemic areas in Brazil has varied from 1.9 to $25 \% 12,13,14,15$

The present study discusses the identification of a dog with characteristic symptoms and diagnosis of canine visceral leishmaniasis by indirect immunofluorescence (IIF) and polymerase chain reaction (PCR) in an urban area of Bom Sucesso, Minas Gerais State, Brazil. The positive IIF led to a canine visceral leishmaniasis epidemiological investigation from 1999 to 2005 to elucidate the situation with canine visceral leishmaniasis in the county and orient the subsequent control and preventive measures by public health authorities.

\section{Methodology}

\section{Target region}

The county of Bom Sucesso is located in southern Minas Gerais State, at 44045'30"W longitude and $21^{\circ} 02^{\prime} 00^{\prime \prime} S$ latitude, with a maximum altitude of $1,230 \mathrm{~m}$ and minimum of $806 \mathrm{~m}$ (Rio Grande) and 940m in the downtown area; mean annual temperature $19.9^{\circ} \mathrm{C}$, mean annual daily high temperature $26.3^{\circ} \mathrm{C}$; mean annual rainfall $1,597.6 \mathrm{~mm}$. The city is located on the banks of the Rio Pirapetinga, part of the Rio Grande water basin and $206 \mathrm{~km}$ from the State capital, Belo Horizonte. The county has a population of 16,949 , with 13,566 in the urban area and 3,383 in the rural area (data from the National Census Bureau, IBGE, for 2000).

\section{Biological material and histopathology}

Peripheral blood samples were collected from each dog (ear) on filter paper to perform IIF at the Ezequiel Dias Foundation in Belo Horizonte. Cerebellum, kidney, liver, and intestine samples were collected from the first IIF-positive dog, preserved in formol, and submitted to paraffin sections. The material was stained with hematoxylin and eosin for histopathological examination at the Department of Histopathology, Federal University in Lavras, Minas Gerais 16, in 1999.

\section{Polymerase chain reaction}

DNA extraction from tissue fragments of cerebellum, liver, kidney, and intestine from the first IIF-positive dog was conducted in 2004 according to Schönian et al. 17. PCR primers were used as described by Marques et al. 18, targeting the constant region of Leishmania kDNA minicircle, generating a PCR product of $120 \mathrm{bp}$.

\section{Immunohistochemistry}

Immunohistochemistry (IMH) was performed in 2005 on the samples of cerebellum, kidney, liver, and intestine from the first IIF-positive dog. In the cerebellum and intestine, organs/tissues in which PCR had shown increased DNA concentration, 100 semi-serial cross-sections of 1:10 preparations were analyzed for each. Peroxidase anti-peroxidase (PAP) staining was then performed according to the methodology proposed by Tafuri et al. 19 .

\section{Serology}

IIF was used to measure total anti-Leishmania IgG in canine sera. Five canine serological surveys were conducted from March 1999 to May 2001, including a serological survey with samples from the canine population present in $5 \%$ of the urban residences in Bom Sucesso. Serum samples were collected from 734 dogs to test for anti-Leishmania IgG. IIF was assessed with total anti-IgG conjugates, diluted at 1:100, marked with fluorescein isothiocyanate (Biomanguinhos, Oswaldo Cruz Foundation, Rio de Janeiro, Brazil). The antigen was obtained from L. (L.) amazonensis promastigote forms (strain MHOM/BR/1960/BH6), fixed in formol at $1 \%$ in saline. IIF titers $\geq 1$ :40 were considered positive 20 .

\section{Entomological survey}

An entomological survey was conducted in June 1999 using luminous CDC-type traps, as proposed by Costa et al. 16. Traps were used in pairs and set up in three different places in the Palmeiras neighborhood in the town of Bom Sucesso. Palmeiras was chosen because it was where the first seropositive dog with visceral leishmaniasis lived. Both traps were set up for three nights in three places. Municipal employees working for the National Health Foundation [FUNASA; Fundação Nacional de Saúde] conducted this work. 


\section{Results}

In March 1999, IIF was positive at 1:40 for the first dog with symptoms characteristic of canine visceral leishmaniasis, from downtown Bom Sucesso. This eight-year-old German shepherd presented apathy, onychogryphosis, and diffuse hair loss. A month after the first serological examination the animal presented IIF conversion to 1:160. Microscopic examination for Leishmania amastigotes conducted in 2003 in tissues from this dog was negative. However, inflammatory infiltrate was observed with the presence of giant cells in cerebellum and kidney samples, examined in 2003. Furthermore, the PCR performed in 2004 was positive for Leishmania DNA in the cerebellum, liver, kidney, and intestine (Figure 1). IMH performed in 2005 did not detect any amastigotes or Leishmania antigens in the abovementioned organs.

Canine visceral leishmaniasis serological surveys from March 1999 to May 2001, including the first dog detected, showed 22 (3.0\%) IIF-positive animals among the 734 dogs investigated. Three of these seropositive dogs were from Palmeiras, a central neighborhood in Bom Sucesso. Interestingly, the other 19 seropositive samples came from 175 dogs ( $10.8 \%$ prevalence) captured in only two outlying neighborhoods of the town (Nossa Senhora Aparecida and São Judas Tadeu). Among the 22 IIF-positive dogs, six presented some characteristic clinical symptoms for canine visceral leishmaniasis and only two were from another county (Belo Horizonte). Of these IIFpositive dogs, $54.5 \%$ were reactive in dilutions from 1:160 to $1: 640$.

The entomological survey in the county did not detect either Lu. longipalpis or any other sandfly species.

The results of the current investigation were communicated to the proper health agencies (Regional Health Administration and FUNASA) so that control measures could be implemented.

\section{Discussion}

During the geographic dispersion of visceral leishmaniasis in Brazil, the disease acquired periurban characteristics and is now fully urbanized 10,21. Visceral leishmaniasis has already been identified in different neighborhoods in large cities like Rio de Janeiro (Rio de Janeiro State) 5, Teresina (Piauí State) 22, São Luís (Maranhão State) 23, Belo Horizonte 24, and Montes Claros (Minas Gerais State) 25. Visceral leishmaniasis displays endemic-epidemic features
Figure 1

Visualization of PCR products obtained from DNA extracted from tissue samples of the first visceral leishmaniasis IIF-positive symptomatic dog in the county of Bom Sucesso, Minas Gerais State, Brazil, 1999.

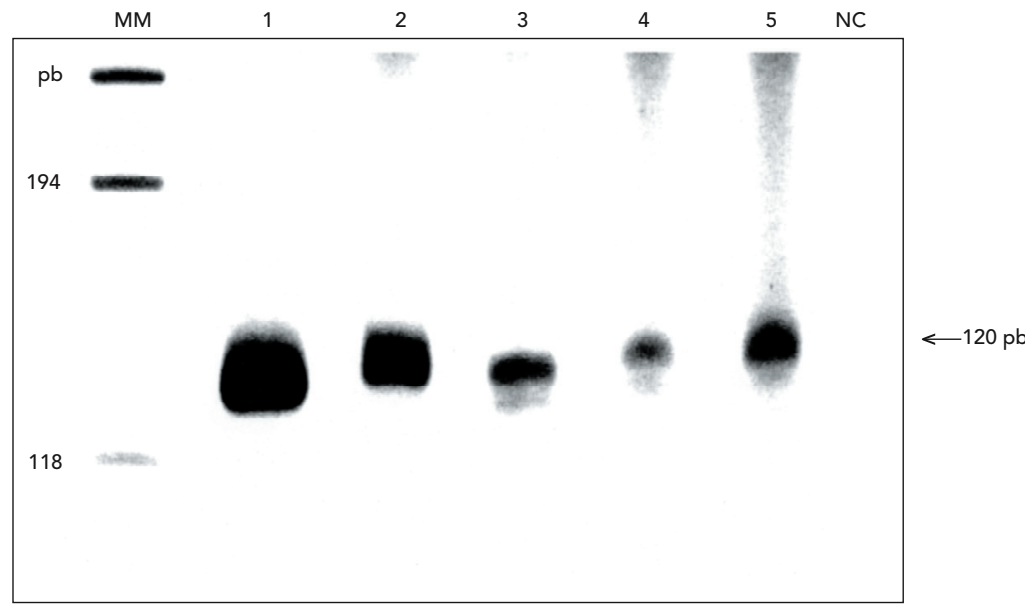

MM - Marker ( $\phi$ X 174 digested with HaellI); 1 - Positive control with DNA from Leishmania (Leishmania) chagasi culture forms; DNA preparations of 2 - Cerebellum, 3 - Liver, 4 - Kidney, 5 - Intestine, NC - Negative control without DNA.

in Brazil, maintaining an annual incidence of 3,000-4,000 human cases, distributed from Roraima to Paraná State 26.

Samples from the first IIF-positive dog did not show Leishmania amastigotes or Leishmania antigens according to histopathology and $\mathrm{IMH}$, respectively. A possible explanation for these unexpected results could be deficient organ specimen preservation. For example, after the dog was sacrificed the carcass was stored overnight in a cold storage facility and the organs were only removed the following day, because the Department of Histopathology at the Federal University in Lavras was closed when it came for examination.

However, this first dog with characteristic symptoms of visceral leishmaniasis and a positive diagnosis by IIF and PCR strongly suggests that it was indeed a new case of canine visceral leishmaniasis. The positive PCR results are considered highly specific and sensitive for detecting Leishmania DNA in canine and human samples 27 . The high IIF serum titers in the present study $(54.5 \%$ were reactive at $>1: 160)$ and the characteristic symptoms were suggestive of $L$. (L.) chagasi infection, thus limiting the likelihood of cross-reactivity 28 . 
The first dog identified and the other IIF-positive animals were all from the urban area of Bom Sucesso and only circulated within the city limits. This tends to confirm the autochthonous nature of this new visceral leishmaniasis area.

From a public health perspective, the concentration of seropositive dogs in two outlying neighborhoods of Bom Sucesso showed a considerably high prevalence (10.8\%) when compared to rates (up to $25 \%$ ) in well-known canine visceral leishmaniasis foci 15. In this serological survey, two IIF-positive autochthonous dogs from Belo Horizonte, a visceral leishmaniasis-endemic area, deserve to be highlighted. The circulation of dogs between Belo Horizonte and Bom Sucesso may have introduced the etiological agent into the latter area, previously non-endemic for the disease.

The main clinical symptoms presented by IIF-positive dogs were onychogryphosis, alopecia, epistaxis, and hematemesis. About 27\% of the IIF-positive dogs that were investigated showed clinical symptoms consistent with canine visceral leishmaniasis. These clinical symptoms and the percentage also agree with previously described data in endemic areas for canine visceral leishmaniasis 3 .

The fact that Lu. longipalpis and other sandfly species were not detected may be due to the small number of capture attempts and the short capture time (June 1999) by FUNASA. June is normally a dry and cold month in the region, which could produce a low vector concentration. However, it should be emphasized that $L u$. longipalpis was captured and identified in 1995 by FUNASA in Santo Antônio do Amparo, only $20 \mathrm{~km}$ from Bom Sucesso.
Thus far there have been no reports of autochthonous human cases of visceral leishmaniasis in Bom Sucesso. It is worth emphasizing that human visceral leishmaniasis is not always related to spatial distribution of canine kalazar. However, infection is more frequent in dogs than human beings and normally precedes the latter 29 . In Belo Horizonte, a large Brazilian city where the Public Health Service is organized in 126 districts, Oliveira et al. 30 found strong evidence that human cases occur in areas where canine prevalence rates are high. This was shown at an ecological level through linear regression used to model the relationship between human incidence rates in a given district and specific year and canine prevalence rates in the same area in the preceding period (six months) 30 . However, no active search for human visceral leishmaniasis cases was performed in Bom Sucesso by health authorities. Thus, the authorities' position was inconsistent with previous recommendations 29 involving similar conditions.

The results of the current study strongly suggest that Bom Sucesso is a new area of autochthonous canine visceral leishmaniasis. However, since the underlying epidemiology has not been fully explained, the county should be included among those subject to heightened canine visceral leishmaniasis surveillance. The authors thus request greater commitment by the local and State public health authorities to conduct an active search for human visceral leishmaniasis cases and intensification of sandfly capture. These measures are crucial for visceral leishmaniasis control and prevention, avoiding spread of the disease and the occurrence of human cases. 


\section{Resumo}

O presente trabalho descreve inicialmente um cão com sintomas característicos de leishmaniose visceral. Amostra de soro desse cão foi positiva por imunofluorescência indireta (IFI) conduzida no IgG total anti-Leishmania em 1999. Além disso, tecidos desse cão foram positivos por reação em cadeia pela polimerase (PCR) conduzida em 2004, identificando DNA de Leishmania no cerebelo, fígado, rim e intestino. Esta é a primeira vez que um cão com leishmaniose visceral autóctone foi descrito no Município de Bom Sucesso, Minas Gerais, Brasil. O achado desse cão reagente à IFI levou a uma investigação epidemiológica nesse município. Essa investigação foi conduzida de março de 1999 a dezembro de 2005. Vinte e dois de um total de 734 (3\%) cães examinados foram reagentes à IFI. Entre os 22 cães IFI reagentes, seis apresentaram sintomas característicos de leishmaniose visceral canina. Os resultados desta investigação epidemiológica foram enviados às autoridades locais e estaduais de saúde pública requerendo medidas preventivas e de controle para leishmaniose visceral de forma a interromper a transmissão da doença e evitar a ocorrência de casos humanos.

Leishmaniose Visceral; Cães; Zoonoses

\section{References}

1. Deane LM, Deane MP. Visceral leishmaniasis in Brazil. Geographical distribution and transmission. Rev Inst Med Trop São Paulo 1962; 4:149-212.

2. Quinnell RJ, Courtenay O, Garcez L, Dye C. The epidemiology of canine leishmaniasis: transmission rates estimated from a cohort study in Amazonian Brazil. Parasitol 1997; 115:143-56.

3. Feitosa MM, Ikeda FA, Luvizotto MCR, Perri SHV. Aspectos clínicos de cães com leishmaniose visceral no município de Araçatuba - São Paulo (Brasil). Clínica Veterinária 2000; 28:36-44.

4. Grimaldi Jr. G, Tesh RB. Leishmaniasis of the New World: current concepts and implications for future research. Clin Microbiol Rev 1993; 6:230-50.

5. Marzochi MCA, Marzochi KBF, Carvalho RW. Visceral leishmaniasis in Rio de Janeiro. Parasitol Today 1994; 10:37-40.

6. Tesh RB. Control of zoonotic leishmaniasis: is it time to change strategies? Am J Trop Med Hyg 1995; 52:287-92.

\section{Contributors}

The six authors participated in various stages of the study and contributed to the article. M. R. Silva and I. C. A. Santa-Rosa analyzed the first symptomatic dog, collected samples from the animal to be preserved in formol and perform paraffin sections, coordinated the field epidemiological studies, organized the databank and data analysis, wrote the first draft, and revised the final version. A. J. Romanha, M. J. Marques, C. M. Carneiro and A. B. Reis conducted the laboratory analysis in samples from the first IIF-positive dog (PCR, immunohistochemistry, and histopathology), participated in the data analysis, and helped write the draft and review the final version.
7. Arias JR, Monteiro PS, Zicker F. The re-emergence of visceral leishmaniasis in Brazil. Emerg Infect Dis 1996; 2:145-6.

8. Grimaldi Jr. G, Tesh RB, McMahon-Pratt D. A review of the geographic distribution and epidemiology of leishmaniasis in the New World. Am J Trop Med Hyg 1989; 44:687-725.

9. Gomes AC. Sandfly vectorial ecology in the state of São Paulo. Mem Inst Oswaldo Cruz 1994; 89:45760.

10. Santa Rosa ICA, Oliveira ICS. Leishmaniose visceral: breve revisão sobre uma zoonose reemergente. Clínica Veterinária 1997; 11:24-8.

11. Silva ES, Gontijo CMF, Pacheco RS, Fiúza VOP, Brazil RP. Visceral leishmaniasis in the metropolitan region of Belo Horizonte, State of Minas Gerais, Brazil. Mem Inst Oswaldo Cruz 2001; 96:285-91. 
12. Coutinho SG, Nunes MP, Marzochi MCA, Tramontano N. A survey for American cutaneous and visceral leishmaniosis among 1342 dogs from areas in Rio de Janeiro (Brazil), where the human disease occur. Mem Inst Oswaldo Cruz 1985; 80:17-22.

13. Iverson LB, Camargo ME, Villanova A, Reichmann MIAB, Anarade EA, Tolenzano JE. Inquérito sorológico para pesquisa de leishmaniose visceral em população canina urbana no Município de São Paulo, Brasil (1979-1982). Rev Inst Med Trop São Paulo 1983; 25:310-7.

14. Magalhães PA, Mayrink W, Da Costa CA, Melo MN, Dias M, Batista SM, et al. Calazar na zona do Rio Doce-Minas Gerais. Resultado das medidas profiláticas. Rev Inst Med Trop São Paulo 1980; 22:197202.

15. Sherlock IA, Almeida SP. Notas sobre leishmaniose canina no Estado da Bahia. Rev Bras Malariol Doenças Trop 1970; 22:231-42.

16. Costa JML, Costa CHN, Vieira JB, Oliveira-Lima JW, Badaró R, Monteiro OS. Controle, diagnóstico e tratamento da leishmaniose visceral (calazar). Brasília: Ministério da Saúde; 1999.

17. Schönian G, Nasereddin A, Dinse N, Schweynoch C, Schallig HD, Presber W, et al. PCR diagnosis and characterization of Leishmania in local and imported clinical samples. Diagn Microbiol Infect Dis 2003; 47:349-58.

18. Marques MJ, Volpini AC, Genaro O, Mayrink W, Romanha AJ. Simple form of clinical sample preservation and Leishmania DNA extraction from human lesions for diagnosis of American cutaneous leishmaniasis via polymerase chain reaction. Am J Trop Med Hyg 2001; 65:902-6.

19. Tafuri WL, Santos RL, Arantes RM, Goncalves R, De Melo MN, Michalick MS. An alternative immunohistochemical method for detecting Leishmania amastigotes in paraffin-embedded canine tissues. J Immunol Methods 2004; 292:17-23.

20. Da Costa CA, Genaro O, De Lana M, Magalhães PA, Dias M, Michalick MSM, et al. Leishmaniose visceral canina: avaliação da metodologia sorológica utilizada em inquéritos epidemiológicos. Rev Soc Bras Med Trop 1991; 24:21-5.

21. Momen H. Emerging infectious diseases-Brazil. Emerg Infect Dis 1998; 4:1-3.
22. Vexenat JA, De Castro JA, Cavalcante R, Tavares JP, Da Silva MR, Batista WH, et al. Visceral leishmaniasis in Teresina, State of Piaui, Brazil: preliminary observations on the detection and transmissibility of canine and sandfly infections. Mem Inst Oswaldo Cruz 1994; 89:131-5.

23. Mendes WS, Trovão JR, Silva AA. The dynamics of territorial occupation and visceral leishmaniasis in the city of Sao Luis, Maranhão state, Brazil. Cad Saúde Pública 2000; 16:872.

24. Genaro O, Da Costa CA, Williams P, Silva JE, Rocha NM, Lima SL, et al. Occurrence of kala-azar in the urban area of Grande Belo Horizonte, Minas Gerais. Rev Soc Bras Med Trop 1990; 23:121.

25. Franca-Silva JC, Da Costa RT, Siqueira AM, Machado-Coelho GL, Da Costa CA, Mayrink W, et al. Epidemiology of canine visceral leishmaniasis in the endemic area of Montes Claros Municipality, Minas Gerais State, Brazil. Vet Parasitol 2003; 111:161-73.

26. Cabrera MAA. Ciclo enzoótico de transmissão da Leishmania (Leishmania) chagasi (Cunha e Chagas, 1937) no ecótopo peridoméstico em Barra de Guaratiba, Rio de Janeiro-RJ: estudo de possíveis variáveis preditoras [Tese de Doutorado]. Rio de Janeiro: Escola Nacional de Saúde, Pública Fundação Oswaldo Cruz; 1999.

27. Silva ES, Gontijo CMF, Pirmez C, Fernandes O, Brazil RP. Short report: detection of Leishmania DNA by polymerase chain reaction on blood samples from dogs with visceral leishmaniasis. Am J Trop Med Hyg 2001; 65:896-8.

28. Marzochi MCA, Coutinho SG, Souza WJ, Amendoeira MR. Leishmaniose visceral (calazar). J Bras Med 1981; 41:61-84.

29. Nunes VLB, Galati EAB, Nunes DB, Zinezzi RO, Savani ESMM, Ishikawa E, et al. Ocorrência de leishmaniose visceral canina em assentamento agrícola no Estado de Mato Grosso do Sul, Brasil. Rev Soc Bras Med Trop 2001; 34:301-2.

30. Oliveira CDL, Assunção RM, Reis IA, Proietti FA Spatial distribution of human and canine visceral leishmaniasis in Belo Horizonte, Minas Gerais State, Brasil, 1994-1997. Cad Saúde Pública 2001; 17:1231-9.

Submitted on 11/Sep/2006

Final version resubmitted on 15/Jun/2007

Approved on 29/Jun/2007 